\title{
Wara' dalam Ajaran Tasawuf Imam Junaid Al-Baghdadi
}

\author{
Abdul Hasib Asy'ari \\ Jurusan Tasawuf dan Psikoterapi \\ Fakultas Ushuluddin UIN Sunan Gunung Djati Bandung, Indonesia \\ abdulhasib210599@gmail.com
}

\begin{abstract}
The peak of Imam Junaid's Sufism is monotheism. One of the efforts to achieve this is the attitude of wara' by always emphasizing on self-awareness so as not to neglect the purpose of the search. This study uses a qualitative approach with data sources obtained from books, books and journals that examine wara', especially the views of Imam Junaid alBaghdadi which aims to determineanalyze the teachings of alJunaid aboutwara' in all aspects of life in order to avoid behaviors that can distance themselves from Allah Swt. This is needed because every individual Muslim should continue to protect himself from bad things and not fall into it. The results showed that wara'in the view of Al-Junaid has a close correlation with the intensity of one's awareness in controlling one's behavior in order to avoid things that can distance oneself from Allah Swt. It develops as far as the knowledge possessed, so that the more mature the knowledge and the intense in applying it, the higher the degree of one's sanity. So it can be concluded that wara' is based on awareness and knowledge to be aware of the behavior of the limbs from temptations that come from outside themselves.
\end{abstract}

Keywords: Imam Junaid al-Baghdadi, Sufism, Wara'.

\begin{abstract}
Abstrak
Puncak tasawuf Imam Junaid adalah tauhid. Salah satu ikhtiar untuk mencapainya adalah sikap wara' dengan selalu menekankan pada kewaspadaan diri agar tidak lalai dari tujuan pencarian. Penelitian ini meggunakan pendekatan kualitatif dengan sumber data yang didapat dari kitab-kitab, buku dan jurnal yang mengkaji tentang wara' terutama pandangan Imam Junaid al-Baghdadi yang bertujuan untuk menganalisa ajaran al-Junaid tentang wara' dalam semua aspek kehidupan agar terhindar dari perilaku-perilaku yang dapat menjauhkan diri dari Allah Swt. Hal ini dibutuhkan sebab setiap pribadi umat Islam selayaknya terus menjaga
\end{abstract}


dirinya dari hal yang buruk dan tidak terjerumus ke dalamnya. Hasil penelitian menunjukkan bahwa wara' dalam pandangan al-Junaid mempunyai korelasi erat dengan intensitas kesadaran seseorang dalam mengendalikan perilaku diri agar terhindar dari hal yang dapat menjauhkan diri dari Allah Swt. Ia berkembang sejauh pengetahuan yang dimiliki, sehingga semakin matangnya pengetahuan dan intens dalam mengaplikasikannya, maka semakin tinggi juga derajat kewara'an seseorang. Sehingga dapat disimpulkan bahwa wara' berlandaskan pada kesadaran dan pengetahuan untuk mewaspadai perilaku anggota tubuh dari godaan yang berasal dari luar diri.

Kata kunci: Imam Junaid al-Baghdadi, Tasawuf, Wara'.

\section{Pendahuluan}

Problematika umat Islam hari ini adalah hilangnya sikap kewaspadaan terhadap diri sendiri dan sekitarnya sehingga menyebabkan hilangnya rasa bertuhan dalam diri dimana hal itu menyebabkan jauhnya ia dari Allah Swt. Tidaklah mengherankan ketika banyak dari umat Islam terjerumus pada hal-hal yang buruk dan bahkan sampai pada taraf sesuatu yang diharamkan oleh syari'at dianggap sebagai hal yang biasa, seperti halnya ketidakhati-hatian dalam bermedia sosial dengan memposting ataupun mengomentari sesuatu tanpa disertai pertimbangan dan pemahaman yang menyeluruh terhadap suatu kasus yang menyebabkan ketersinggungan orang lain di dunia maya, begitu juga dengan perilaku Korupsi, Kolusi dan Nepotisme (KKN), menjadi hal yang lumrah dilakukan dari tataran paling atas hingga masyarakat biasa, berapa banyak menteri yang tersandung kasus korupsi hingga masyarakat yang ingin membuat SIM (Surat Izin Mengemudi) harus membayar dengan nominal tertentu agar bisa lolos ujian mengemudi.

Untuk menjawab krisis kehati-hatian dalam berperilaku, perlulah penanaman nilai tasawuf pada setiap individu terutama tentang wara' agar terbangun sikap kewaspadaan dalam setiap situasi dan kondisi apapun yang melingkupi individu tersebut. Perlu dipahami bahwa tasawuf sendiri bukanlah tentang kondisi penyatuan dengan Tuhan melainkan pengimplementasian tasawuf pada perilaku diri agar tercapai transformasi diri yang lebih baik, ia menjelaskan bahwa hakikatnya tasawuf merupakan proses transformasi seorang salik ketika ia berusaha untuk membebaskan diri dari egosentris, meninggalkan akhlak madzmumah menuju akhlak hasanah serta membentuk karakter kebaikan dalam diri (Kamba, Mencintai Allah Secara Merdeka, 2020, p. 49). 
Proses pembebasan ego diri melibatkan sikap wira'i seseorang untuk selalu terjaga pada sesuatu yang akan dilakukannya dan di hadapannya. Pergolakan dalam diri serta pertimbangan pada aspek di luar diri menjadi tantangan tersendiri dari proses meninggalkan akhlak madzmumah, pergolakan dan pertimbangan inilah yang menjadi bagian dari sikap wara' seseorang. Mengaplikasikan wara' dalam kehidupan mempunyai korelasi dengan kesadaran individual manusia sebagai makhluk yang mempunyai watak "Aku", yang sadar akan keberadaan dirinya dan di luar dirinya.

Imam Junaid al-Baghdadi merupakan seseorang yang mumpuni dalam meberikan paham tasawuf agar tidak gampang disalahpahami oleh masyarakat dan jatuh pada kekeliruan pengejawentahan tasawuf (Kamba, Kidz Zaman Now, 2018, p. 148). Beliau merupakan murid dari Sari asSaqathi dan Abu Harits al-Muhasibi. Sari as-Saqathi merupakan seorang sufi terkenal sebagai sosok yang sangat wara' baik dalam aspek ibadah, makanan, pikiran dan pengendalian hawa nafsu. Ia merupakan sufi yang mendalam tentang pengetahuan tauhid (al-Qusyairi, 2003, p. 10). Sedangkan al-Muhasibi yang merupakan guru kedua setelah Imam junaid belajar pada Sari (al-Hakim, 2005, pp. 13-14).

Imam Junaid hidup di masa Muktazilah yang merupakan madzhab resmi negara. Perdebatan sengit soal teologis serta proses pencarian esensi ketuhanan yang melibatkan disiplin filsafat sebagi pisau serta tasawuf yang menekankan aspek pengalaman spiritual menjadi pokok utama dalam kajian fan keilmuan pada abad itu (Hitti, 2006). Sehingga tidak heran ketika tasawuf yang dikemukakan oleh Imam Junaid lebih pada penggambaran secara menyeluruh tentang pengesaan Allah Swt. Aspek-aspek mengenai etika dan moral tidak menjadi fokus utamannya namun tetap ada dalam serakan-serakan ajarannya. Tekanan-tekanan yang dialami para sufi pada abad itu terutama dari pemerintahan membuat mereka haruslah selalu waspada dalam menampakkan dirinya di khalayak ramai.

Karya Imam Junaid yang masih ada hingga saat ini adalah kitab Rasail al-Junaid yang dihimpun oleh Hasan Abdul Kader. Karya beliau yang menghilang dan didapat hanya berasal dari kesaksian dari sufi-sufi besar sesudahnya yakni al-Munajat yang dikutip as-Sarraj dalam kitabnya alLuma' (as-Sarraj, 1970), Tashih al-Iraidah yang dikutip oleh al-Hujwiri dalam kitabnya Kasyful Mahjub (al-Hujwiri, 2007). Karya Imam Junaid yang sampai saat ini dapat dikatakan tidak terlalu banyak, hal ini dikarenakan jarangnya penggunaan kertas sebagai medium penyebaran ajarannya. Ia lebih menyukai majlis ilmu dan dialog untuk mengajarkan paham tasawufnya, Imam Junaid juga tidak menyebarkan ajarannya kepada cakupan yang lebih luas. Hanya murid dan segelintir orang yang ia percayai untuk mengetahui ajarannya. Hal ini dikarenakan kekhawatirannya akan kesesatan dan kesalahpahaman dalam mebaca karya-karyanya (Kader, 2018). 
Penelitian mengenai Imam Junaid dan paham tasawufnya sudah banyak dikemukakan oleh beberapa peneliti. Beberapa di antaranya adalah Sholahuddin Ashani, Raja Perkasa dan Maulani yang meneliti Trilogi Pemikiran Tasawuf Imam Junaid al-Baghdadi (Mitasq fana' dan Tauhid) (Maulani, 2021). Penelitian ini berfokus pada ajaran metafisika Imam Junaid al-Baghdadi yang menjabarkan bagaimana seorang sufi dapat terus terjaga dalam tauhid pada Allah Swt. sedang ia dalam kondisi hidup di dunia materil. Kemudian Asrar Mabrur meneliti tentang Wawasan Hadits Nabi tentang Wara', dimana hadits-hadits tentang wara' dijelaskan dan dianalisa dengan riwayatul hadits, untuk mengemukakan bahwa mistisisme Islam tidak bertentangan dengan dalil nash terutama hadits (Faza, Maret 2017). Muhammad Nursamad Kamba meneliti konsep Ma'rifat Imam Junaid desertasi ini difokuskan pada epistemologi pengetahuan dalam pandangan al-Junaid, meliputi metode serta bentuk pengetahuan dari Tuhan (Kamba, Kidz Zaman Now, 2018).

Kajian ini meneliti pada perilaku Imam Junaid dalam menjaga dirinya baik aspek internal diri maupun ketika dihadapkan pada hal duniawi yang teraktualisasi dalam serakan-serakan ajaranya Sikap yang mewakili perilaku tersebut yakni ajaran wara'yang meliputi pada kehatian-hatian seorang sufi dari godaan dalam diri maupun dari luar diri yang dapat membuatnya jauh dari Allah Swt. sebagaimana gurunya yakni Harits alMuhasibi mengatakan "مجانبة ما كره الله جل و عز" (wara' adalah menghindari segala sesuatu yang dibenci Allah Swt.)" (al-Muhasibi, 1956). Kata "mujanabah" dalam bahasa Arab berada pada konteks sesuatu berdekatan dengan sesuatu hingga kemudian dihindarkan agar tidak dekat, karena potensi alamiah manusia adalah selalu berdekatan dengan hal yang baik dan buruk. Terlebih juga Nabi pernah bersabda: "ملاك دينكم الورع (Prinsip agamamu adalah wara) (as-Sarraj, 1970, p. 70).

\section{Metode Penelitian}

Penelitian ini merupakan penelitian kepustakaan (library research) dengan menggunakan pendekatan kualitatif (Darmalaksana, Metode Penelitian Kualitatif Studi Pustaka dan Studi Lapangan, 2020). Data penelitian didapatkan dan dianalisis berdasarkan pada teks-teks tertulis yang berkaitan dengan tema yang diteliti (Zed, 2014, pp. 1-2). Kemudian metode yang digunakan dalam penelitian ini adalah analisis konten (content analysis) dimana metode ini memiliki tujuan untuk membuat inferensi yang dapat diteliti ulang dan valid dari data berdasarkan konteks penggunaannya. Penelitian ini biasanya dilakukan untuk menganalisis suatu informasi yang didokumentasikan baik melalui rekaman, gambar, suara ataupun tulisan (Novianto \& Mustadi, 2015, p. 8). Dokumen atau kitab yang dianalisis dalam penelitian ini adalah Rasail al-Junaidi yang ditulis oleh iman Junaid al-Baghdadi. Tujuannya adalah untuk mengetahui 
pesan simbolik mengenai tema yang dikaji, serta dapat meng-ekstrak pemikiran dan ajaran tasawuf Imam Junaid al-Baghdadi terutama mengenai konsep wara'.

Terdapat dua jenis sumber data yang digunakan dalam penelitian ini yaitu data primer yang merupakan karya imam Junaid al-Baghdadi kitab Rasaîl al-Junaid dan data sekunder yang berasal dari jurnal, buku dan artikel yang membahas ajaran imam Junaid al-Baghdadi. Beberapa data pendukung yang digunakan dalam peneltian ini adalah Imam Junaid pemimpin para sufi karya Ali Hasan Abdel Kader, al-Luma' karya as-Sarraj, Risalah Qusyairiah karya al-Qusyairi, Kasyful Mahjub karya al-Hujwiri dan lain-lain.

Penelitian ini berlandaskan dari ajaran-ajaran wara' yang berasal dari guru al-Junaid terutama dua guru utamanya yakni Sari as-Saqathi dan Abu Harits al-Muhasibi kemudian dikompharsikan dengan ajaran-ajaran Imam Junaid yang mendukung ataupun yang berkenaan dengan aspek wara' agar terdapat kejelasan arah dan esensi wara' menurut Imam Junaid alBaghdadi.

\section{Hasil dan Pembahasan}

\section{Ajaran Tasawuf Imam Junaid al-Baghdadi}

Imam Junaid al-Baghdadi mendefinisikan tasawuf sebagai ikhtiar seorang manusia, dimana disanalah ia tinggal, serta dalam keterangan yang lain bahwa usaha untuk dapat bersama dengan Allah tanpa menghiraukan yang lain (Kader, 2018, p. 155). Kebersamaan di sini dalam bentuk antara engkau bersama Allah tanpa embel-embel (penghalang), dimana proses transformasi diri yang dilakukan seorang sufi untuk mencapai Tauhid bukan atas dasar dirinya sendiri, melainkan atas dasar karena Allah Swt. itu sendiri (Kamba, Mencintai Allah Secara Merdeka, 2020, p. 49).

Intisari ajaran Imam Junaid terletak pada dua doktrin utamanya yaitu doktrin tentang tauhid dan doktrin tentang ketenangan jiwa (sahw). Dua doktrin ini melibatkan dua kondisi kesadaran manusia yang menjadi doktrin tasawuf pada masa itu, yakni kesadaran yang diambil alih oleh Tuhan dan membersamainya serta kesadaran aku sebagai subjek yang hidup di dunia. Hal ini dikarenakan bagi Imam Junaid bahkan seorang sufi pun tetap tidak akan terlepas dari kondisi normal sebagai seorang manusia, inter subjektif dan objek, yang mempunyai korelasi kesadaran tersebut dengan subjek lain. Selama manusia hidup di dunia tubuh tetaplah menjadi pembatas antara dirinya untuk terus menerus diambil alih kesadarannya oleh Allah Swt. Dalam tasawufnya, Imam Junaid menjelaskan bahwa tauhid merupakan: 


$$
\text { فيكون كما كان قبل أن يكون القراد القدي عن الحدث, و في الكتاب الرسالة للامام القشيرى أنه قال : وهو ان يرجع اخر العبد الى أوله, }
$$

“Tauhid merupakan pemisahan sesuatu yang kekal dengan yang memiliki awal mula" (al-Hujwiri, 2007, p. 521). Dalam kitab Risalah karya Imam al-Qusyairi disebutkan bahwasanya Imam Junaid berkata "Tauhid merupakan kembalinya seorang hamba kepada tujuan awalnnya, maka jadilah ia seperti halnya sebelum ada (berwujud)" (al-Junaid A. a.-Q., 1988, p. 61).

Sahw (ketenangan hati) merupakan kondisi setelah mabuk kepayang dalam kebersamaan dengan Tuhan menuju kesadaran dirinya yang dapat merenungi segala sesuatu untuk menempatkannya sebagaimana tempatnya, untuk menegaskan kembali sifat individunya yang telah diberitahu Tuhan dengan masih tetapnya sisa kebersamaannya dan mengamalkan perilaku Tuhan yang diajarkan padanya setelah ia telah mengecap puncak kekayaan Allah Swt. (al-Junaid A. Q., 1988, p. 58). meskipun dua kondisi ini yang mejadi kondisi ideal bagi seorang sufi, terdapat keadaan lain yang berbarengan seperti halnya fanâ, mitsấ, bala dan lain-lain yang telah Imam Junaid kemukakan dengan jelas dalam risalah-risalahnya dan tulisannya.

Wara' dalam ajaran tasawuf Imam Junaid al-Baghdadi, terletak dalam doktrinnya tentang sahw, yakni ketika manusia berada pada kesadaran normalnya pada saat proses pencarian pada Allah Swt. hingga tiba pada fase fan $a^{*}$ yang berujung pada tauhid, hingga dikembalikan lagi pada kesadaran normalnya. Seorang salik di kondisi normalnya harus selalu awas pada semua yang hal yang ada dalam dirinya maupun di luar dirinya agar tidak terjatuh pada perkara-perkara yang dapat menjauhkannya dari Allah Swt.

Wara' (sikap kehati-hatian) terus ia tekankan pada murid dan sahabat-sahabatnya dengan tujuan menghindari terjerumusnya individu dalam hasrat duniawi, tujuan lainnya adalah sebagai kontrol rahasia para pengamal tasawuf agar tidak tersebar luas pada khalayak umum yang berujung pada kekeliruan dalam memahami. Selain itu sikap ini tidak akan mengganggu stabilitas sosial sehingga para penempuh suluk tidak akan diganggu oleh para penguasa (Kader, 2018).

Pemahaman dan pengamalan yang mendalam terhadap sikap wara' dalam setiap sendi kehidupan dapat menjadi tameng bagi diri untuk tidak terjerumus pada hal-hal yang dilarang agama. Memanglah sifat alamiah manusia sering lalai dan lupa, baik pada dirinya maupun sekitarnya, namun dengan mengamalkan wara' dapat membentuk kebiasaan baru untuk tidak menjadikan gampang pada perilaku-perilaku yang dapat menjadi sebab jauhnya diri pada Allah Swt. 


\section{Kajian tentang Wara'}

Abu Harits al-Muhasibi mendefinisikan bahwa wara' adalah menjauhi perbuatan yang dibenci oleh Allah Swt., melingkupi aspek emosi, jasmani dan perbuatan hati. Muhasabah menurutnya berkorelasi dengan sikap wara' dimana adanya kepastian dalam hati, meninggalkan perbuatan yang menyimpang sehingga mengerti dengan jelas pada apa yang harus ditinggalkan dan yang harus dikerjakan sebagaimana perkataan Umar bin Khattab "warriu al-lisha walâ tara'ûhu" hindarilah pencuri dan jangan engkau mengikutinya (al-Muhasibi, 1956, p. 42). Wara' dalam pandangan al-Junaid merupakan sikap kehatia-hatian (kewaspadaan) diri dari hal-hal yang dapat memalingkan diri dari Allah Swt. Seseorang dikatakan wara' yakni ketika dihadapkan pada suatu perkara, ia memperhatikan dan berhati-hati pada setiap hal yang kecil (al-Mazidi, 2006, p. 179).

Dari hal ini dapat dipahami bahwa wara' merupakan perilaku seseorang yang selalu berlandaskan pada agama, bertolak dari usaha untuk selalu mewaspadai pada segala pekara hingga yang kecil sekalipun. Kemudian memantapkan hati pada arah meninggalkan perkara ataupun meninggalkannya yang sekiranya dapat menyebabkan ia mendapat derajat yang tinggi di sisi-Nya.

Ajaran tasawuf Imam Junaid tidak terlepas dari pengaruh kedua guru utamanya yaitu Sari as-Saqathi dan Abu Harits al-Muhasibi, keduanya merupakan seorang yang wara' terhadap hal-hal yang duniawi, pondasi utama ajaran tasawufnya adalah Al-Qur'an dan as-Sunnah. Dalam wara' tidaklah diri seseorang terlepas dari sifat buruk namun bagaimana ia dapat menghidari dan mewaspadai hal tersebut, ia merupakan tangga awal dalam menapaki salik serta tameng bagi manusia agar tidak terjermus pada melakukan hal yang dibenci Allah Swt. Inilah yang membedakan antara wara' dan zuhud, dimana efek selanjutnya dari kematangan wara' adalah zuhud itu sendiri (as-Sarraj, 1970, pp. 70-74).

\section{a) Urgensi Wara'}

Nabi Muhammad Saw. bersabda: "ملاك دينكم الورع (Prinsip agamamu adalah wara)" (as-Sarraj, 1970, p. 70). Inti dari adanya syariat adalah berlandaskan pada maqaîidus syari'ah, berprinsipkan wara' (kehati-hatian) dalam berbagai hal serta bertujuan agar manusia kembali pada asal penciptaan yakni bersatu kembali dengan penciptanya, agar selaras apa yang dikehendaki pencipta pada ciptaannya terutama manusia yang berperan sebagai khalifah fil ardh. Secara teoritis wara' memanglah sederhana yaitu meninggalkan hal yang haram dan apa yang dapat menyebabkan diri jauh dari Allah Swt. Haram dan halal sudah sangat jelas dalam ajaran syariat Islam, hanya ada perbedaan dalam hal furu' saja yang bergantung ijtihad ataupun ijma' dari mujtahid, kehalalan bersandar pada kebaikan dan keharaman bersandar pada hal-hal yang membahayakan dan 
merugikan bagi manusia secara logis yang dapat diterima oleh semua orang. Hal ini diperkuat oleh sabda Rasulullah Saw.:

$$
\begin{aligned}
& \text { الحلال بين والحرام بين وبين ذلك أمور مشتبهات لا يدري كثير من الحرام فمن تركها إستبرأ لدينه وعرضه الناس أمن }
\end{aligned}
$$

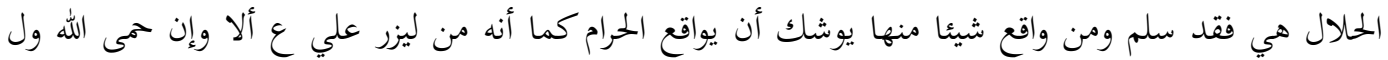

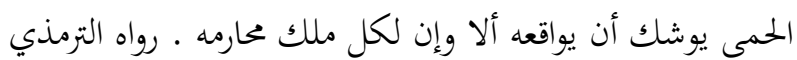

"Sesuatu yang halal sudah jelas dan sesuatu yang haram sudah jelas, di antara keduanya merupakan perkara syubhat yang tidak diketahui kebanyakan orang. Barang siapa yang takut pada barang syubhat maka terbebaslah agamanya dan harga dirinya. Barang siapa yang jatuh pada syubhat maka sesungguhnya jatuh pada perkara haram" (HR. Turmudzi hadis No. 1205).

Dari hadits ini dapat dipahami bahwa salik ketika mengingkinkan derajat kedekatan dengan tuhannya, maka ia harus berusaha untuk menjaga dirinya dari hal-hal yang haram bahkan pada sesuatu yang status hukumnya tidak jelas. Sikap wara' hendaknya sebagai nilai yang terus dijaga karena ia mencakup pada aspek fisik dan bathin agar salik senantiasa berada di jalur yang dibenarkan oleh agama.

\section{b) Dimensi Wara'}

Wara' merupakan perilaku selektif dalam segala hal, seseorang dapat disebut sebagai orang yang wira'i ketika ia mampu menjaga seluruh anggota tubuhnya dari hal-hal yang haram dan hal yang tidak diperbolehkan di antara anggota tubuh tersebut yang menjadi pokok perhatian agar terhindar dari keharaman dan kesubhatan adalah mata dan telinga, lisan, perut dan hati. Dimensi yang menjadi batasan dari perilaku wara' mencakup pada dzahir dan bathin, dzahir melingkupi perilaku diri dan anggota tubuh dan bathin melingkupi pada kewaspadaan agar hati tidak terpaut pada apapun kecuali hanya pada Allah Swt. (As-Sahmarani, 1987).

Dalam pengimplementasiannya, wara' tidak lepas dari beberapa ajaran lain dari tasawuf yang berkesinambungan dengannya salah satunya adalah muhasabah. Sebagaimana dijabarkan oleh al-Muhasibi, "Perhatian kesadaran diri pada hal-hal yang berkenaan dengan apa yang harus ditinggalkan dan diwaspadai dapat menjauhkan diri pada Allah Swt." (alMuhasibi, 1956). Tentunya membutuhkan koreksi terus menerus dalam diri untuk memilah dan memilih sesuatu secara parsial kemudian memutuskannya untuk meninggalkannya. 


\section{1) Mata dan Telinga}

Ketika al-Junaid bermimpi bertemu iblis, ia bertanya tentang apa yang dapat ia capai dari menggoda sahabat-sahabatnya, iblis menjelaskan dengan berkata:

$$
\text { فقال : إنه يع سر على شأغم ، ويعظم على أن أصيب منهم شيئا ، إلا في وقتين . قلت : أي وقت ؟ قال : وقت }
$$

"Sesungguhnya (selama ia menggoda) mereka sibuk dengan urusannya (ibadah) hal itu menyusahkanku, dan mempersulitku untuk menimpakan sesuatu pada mereka, kecuali pada dua waktu, aku bertanya: waktu apa itu?, ia menjawab: waktu mendengar dan ketika melihat, sesungguhnya aku memikat mereka dengan mata dan menyisipkan hasutan pada mereka melaui telinga" (al-Hakim, 2005, p. 92).

Mata merupakan indra penangkap stimulus yang paling banyak dalam merangsang pikiran, ia memiliki andil yang besar bagi hati dan akal dalam memutuskan setelah rangsangan dari luar masuk melewati stimulus indra mata. Sehubungan dengan hal ini al-Ghazali menjelaskan bahwa mata harus dijaga dari empat perkara yaitu memandang wanita yang bukan muhrimnya, melihat wajah yang disertai syahwat karena dapat menimbulkan fitnah, melihat orang lain dengan pandangan hina dan meremehkan, serta melihat aib orang lain.

\section{2) Lisan}

Imam Junaid berkata:

$$
\text { قال الجنيد : الورع في الكلام أشد منه في الاكتساب }
$$

"Wara' (berhati-hati) dalam ucapan lebih utama dibandingkan perilaku" (al-Mazidi, 2006).

Lisan sebagai alat interaksi manusia dengan sesama memiliki peranan yang penting dalam berhubungan sosial dan dialog pada diri, tidak seperti mata yang hanya penerima rangsangan, lisan dapat menjadi pemberi rangsangan dan juga sekaligus penerima. Lisan harus dijaga agar tidak sampai mengeluarkan hal-hal yang kurang baik. Al-Ghazali mengingatkan bahwa lisan harus dijaga dari perkataan dusta, ingkar janji, ghibah, berdebat dengan tujuan mempermalukan atau menjatuhkan lawan bicara serta menjelek-jelekan orang lain.

\section{3) Perut}

Dalam pandangan Islam, makanan yang dikonsumsi manusia dianggap sangat penting dan mendapatkan perhatian yang serius, 
makanan yang masuk pada perut manusia akan dicerna dan menjadi daging, diyakini yang akan mempengaruhi kehidupan individu tersebut, oleh karenanya Allah mengingatkan dalam QS. Abasa 80: 24 yang berbunyi: "Maka hendaklah manusia memperhatikan pada makanannya."

Perilaku sufi yang berhubungan dengan perut hanya dicukupkan pada kebutuhan saja, yaitu ketika benar-benar lapar dan tidak berlebihan hingga kekenyangan sesuai dengan tuntunan dari Nabi Muhammad Saw. Junaid menjelaskan keistimewaan perut yang terjaga dari keharaman dan berlebihan, ia berkata:

$$
\text { الجوف إذا خلا من الامتلاء ، كان أرق للقلب ، وأعذب للتلاوة ، وأدوم القيام ، وأقل للمنام }
$$

Perut yang kosong dapat memperlembut hati, meringankan diri untuk membaca al-Qur'an, senantiasa kuat untuk berdiri (beribadah) dan mempersedikit tidur (al-Hakim, 2005, hal. 155).

Al-Junaid kemudian mejelaskan kondisi menyeluruh pada orang sufi ketika menjaga perut, lisan dan pendengarannya.

$$
\begin{aligned}
& \text { تنزل الرحة ( من الله عز ذكره على الفقراء ، يعني الصوفية ، في ثلاثة مواطن : عند اكلهم الطعام فإِفم لا بأكاون }
\end{aligned}
$$

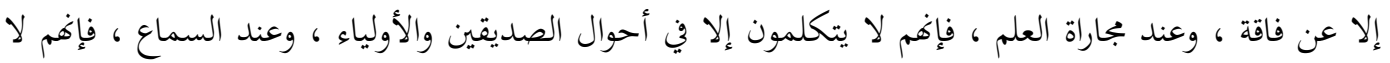

$$
\begin{aligned}
& \text { يسمعون إلا من حق ، ولا يقومون إلا بوجده }
\end{aligned}
$$

Turunnya rahmat dari Allah Swt. pada orang faqir, yakni orang-orang sufi, dalam tiga kondisi: ketika memakan makanan, karena mereka tidak makan kecuali di waktu sangat lapar/butuh, ketika mengkaji ilmu, karena mereka tidak akan berkata kecuali di sekitar orang jujur dan wali, serta ketika mendengar, karena sesungguhnya mereka sufi tidak mendengar kecuali pada suatu kebenaran (as-Sarraj, 1970, hal. 154).

\section{4) Hati}

Imam Junaid berkata:

$$
\text { القلوب المففوظة لا يعرضها وليها ، لمجانية محادثة غيره }
$$

"Hati yang terjaga adalah hati yang tidak ditentang oleh pemiliknya untuk menjauhi hal yang buruk (al-Qusyairi, 2003).

Hati adalah sejenis wawasan batin atau intuisi dalam diri manusia, sebagai alat yang terhubung langsung dari Tuhan untuk mendapatkan pengalaman mistis ataupun pengetahuan dari Tuhan (Iqbal, 2016, hal. 17). Pandangan hati terganggu ketika manusia lebih memilih mengikuti hasrat nafsunya ataupun terjebak dalam pengetahuan akalnya oleh karenanya Imam Junaid menganjurkan untuk selalu waspada dalam mengira perilaku 
hati, menganggap telah sampai dan dipilih oleh Allah Swt., begitu juga dengan terjebak dengan menyembah pada sesuatu selain Allah sekalipun hal sepele (al-Junaid A. Q., 1988). merupakan hal yang sangat sulit untuk dihindari pada zaman ini, mudahlah berkata tidak berpaling pada duniawi, namun untuk selalu terjaga agar tidak terpaut pada materi karena berbagai macam kebutuhan adalah sebuah keniscayaan yang sukar.

Selain menjaga perilaku dan anggota tubuh, wara' dalam pandangan al-Junaid sangat berkaitan erat dengan kesadaran manusia sebagai seorang subjek. Di mana ia mengemukakan bahwa dalam pencapaian anugrah tauhid, manusia mengalami beberapa kondisi yang melibatkan pada pengoptimalan semua potensi dalam diri manusia mengenai kondisi tersebut agar terdapat kesadaran yang dinamis, kesadaran manusia bertingkat sejauh mana usaha ia dalam mendekatkan diri, hingga kemudian Tuhan menganugrahkannnya dengan mengenalkan diri-Nya (Kader, 2018, pp. 223-226). Tentang dinamisnya kesadaran hal senada diungkapkan Iqbal, bahwa kesadaran merupakan suatu tegangan, keadaan swa-intensi (self-consentration), yang melaluinya hidup mampu menutup kenangan dan ikatan yang tidak lagi memiliki hubungan dengan kondisi dan tindakan saat ini, kesadaran tidak memiliki batas tepi, ia dapat menyempit dan meluas menurut kebutuhan (Iqbal, 2016, hal. 47). Ketika sesorang mengfokuskan kesadarannya untuk selalu awas pada semua kondisi saat ini dan dijaga dari fokus ke arah lain yang dapat membuatnya lupa pada Allah Swt, maka akan dapat secara perlahan ia dapat mengendalikan intensitas kesadarannya serta sikap wara' akan teraktualisasi sebagai kebiasaan alamiah yang dimiliki seorang salik.

Sikap wara' berkembang sejauh mana kematangan pengetahuan dan prinsip seorang hamba, al-Junaid menjelaskan bahwa seorang cendikiawan yang sedang menempuh jalan untuk mendapatkan pengetahuan sejati lebih dahulu dituntun oleh pengetahuan dirinya sekalipun pengetahuan tersebut juga adalah anugrah Tuhan. Ia akan terus mewaspadai pada apa yang diketahuinya mengenai sesuatu, seperti halnya sesorang yang mendengarkan ceramah dari orang pandai, dia pikir telah memahaminya namun ternyata ia masih berada dalam keremangan dan tidak benar-benar bisa memahami topik tersebut, maka berhati-hatilah orang yang memakai jubah pengetahuan namun gagal memahami wujud murni pengetahuan (al-Junaid A. Q., 1988, pp. 8-9).

Meningkatnya sikap wara' dalam diri hamba sangat dipengaruhi oleh pengetahuan sejati oleh Allah Swt., orang yang masih belum pernah mencapai kefanaan akan berpatokan pada sikap kehati-hatiannya atas dasar pengetahuan dzahiriyah, kemudian orang yang sudah melewati fase fana' akan lebih tercerahkan lagi intensitas pengetahuannya dan kesadarannya, hingga ketika ia telah mencapai puncak tauhid dan melewati fana' demi fana' maka ketika ia kembali pada kesadaran 
normalnya ia tidak akan berucap dan berperilaku tidak sesuai dengan apa yang diajarkan Allah Swt. padanya.

Wara' dalam konsep tasawuf al-Junaid merupakan pondasi dasar dari ajarannya, dimana ia teraktualisasi dalam sikap bijak dan kehati-hatian alJunaid. Dia mendorong pada ketenangan hati dan mengajarkan penerimaan pada sebuah kemungkinan atau penyingkapan hijab ilahi, pada penjagaan hubungan kemesraan dengan tuhan secara rahasia, menghindari jalan yang berbahaya yang memungkinkan kontroversi dalam sosial dan rasa kebersamaan, dimulai dari sebuah kewara'an kemudian memunculkan ketenangan hati (sahw) (Nasr, 2002, pp. 105-106).

\section{c) Tingkatan Wara'}

Wara' meliputi kewaspadaan terhadap segala apa yang diketahui dan akan dilakukan seorang manusia, dalam berbagai macam kondisi dan posisi seorang salik. Oleh karena itu dapat dikategorikan wara' menjadi tiga bagian, yaitu:

\section{1) Wara' Awam}

Imam al-Junaid Berkata "Seandainya aku hidup seribu tahun, sungguh sebutir debu pun aku tidak akan mengurangi kewajibanku terhadap Allah Swt." Ada kategori ini tidak terlepas dari ajaran halal dan haram dalam agama, bukan sekedar aspek makanan, melainkan pada apa yang telah agama perintahkan terhadap diri manusia, ketika dihadapkan pada dua hal yang masih belum jelas dalam aturan agama maka memilih untuk meninggalkannya (as-Sarraj, 1970). Tatkala seseorang dihadapkan pada hal yang yang dilarang dalam agama seperti halnya berlaku curang, korupsi dan tindakan yang merugikan orang lain, maka wari' akan lebih memilih untuk menjauhinya. Penjelasan ini dikira cukup karena hal yang berkaitan dengan halal dan haram telah diperincikan dalam berbagai cabang keilmuan agama Islam yang sifatnya mengikat bagi pemeluknya.

\section{2) Wara' Khawas}

Wara' khawas dalam pandangan al-Muhasibi merupakan kehatihatian terhadap bisikan hati, dorongan nafsu dan kesalahan persepsi akal (al-Muhasibi, 1956, p. 41). Hal ini dipertegas oleh Imam Junaid dalam risalahnya mengenai korelasi tiga unsur tersebut dalam aspek wara' yakni “Maka pakailah sekarang jubah wira'i, ambilah pakaian taqwa, berdirilah dihadapan Allah Swt. dengan menjaga selalu penghambaanmu, selalu berhati-hati, selalu mempertimbangkan setiap perbuatan, bergegas melaksanakan kebaikan (hasil), benarnya dorongan pencarian, maka akan tercapai sir (rahasia) beserta hal itu didapatkan dengan selalu berdzikir dan kuatnya intelektual" (al-Junaid A. Q., 1988, p. 15). 
Akal harus terus diwaspadai karena acap kali akal salah dalam mempersepsikan sesuatu disebabkan ia tergoda akan kemewahan dunia dan penguasa, silau oleh emas, tipu daya dan keharamannya, sadar akan kekeliruan metode namun dilupakan akibat terlalu bersandar pada pengetahuan (al-Junaid A. Q., 1988). Akal merupakan buah dari fikiran yang berfungsi menerima pengetahuan dari indra dan rasa, akibat dari ketidakwaspadaan seorang manusia dapat menjadikan akal menjadi tumpul dalam memahami. Efek yang akan ditimbulkan adalah liarnya akal tidak terkendali serta jatuh pada kepentingan duniawi saja. Oleh karenanya, perlulah seorang manusia untuk memahami suatu hal dengan hati-hati dan kesadaran penuh (al-Junaid A. Q., 1988).

Seperti halnya akal, nafsu adalah potensi alamiah yang dimiliki manusia yang memiliki daya dorongan atau hasrat dalam diri manusia, nafsu adalah sesuatu yang menjadi pendorong atau pengaruh pada adanya sifat-sifat manusia yang terimplikasi pada akhlak dan perilaku seorang hamba tercela (al-Qusyairi, 2003, p. 93). Agama tidak mengajarkan untuk melawan nafsu, melainkan mengontrolnya agar dorongan tersebut terarah pada hal yang baik, oleh karenanya Allah berfirman dalam Al-Qur'an tentang nafsu al-muthmainnah. Imam Junaid mengingatkan bahwa seseorang harus berhati-hati pada kemalasan yang akan mengakibatkan pada berkurangnya keteguhan diri serta waspada pada hasrat untuk dipuji dan dihormati sebagai sebuah imbalan atas pengetahuan (al-Junaid A. Q., 1988, p. 22). Hal ini sering kali terjadi pada para cendikiawan yang mengajarkan pengetahuannya, karena ia sudah mengajarkan pengetahuan maka ia merasa harus dihormati dan dihargai. Menghormati dan menghargai memanglah keharusan dalam aspek etika, namun dorongan merasa diri haruslah dihargai tidaklah boleh tersemat dalam diri manusia.

\section{3) Wara' Khawasul Khawas}

Tingkatan paling sulit dari wara' adalah khawasul khawas, dimana seseorang mewaspadai dirinya agar tidak lalai dari Allah Swt., baik tiga daya yang dimiliki manusia yakni nafsu, akal dan hati hingga wujud fisik manusia. Dalam salah satu suratnya pada Amr al-Makki, al-Junaid mengingatkan pada sahabatnya serta dirinya agar menjaga diri untuk tidak lalai dari Allah Swt., sehingga dapat menyebabkan ia menjauh dari diri mereka (al-Junaid A. Q., 1988, p. 8). Hal ini menunjukkan bahwasanya orang yang mencapai maqam tauhid tidak akan lepas dari rintangan kelalaian, acap kali diri manusia lalai dalam mengingat-Nya namun harus cepat-cepat kembali, keinsyafan yang dilakukan harus selalu diupayakan agar tidak terjebak pada kelalaian darinya. Selain menjaga dari kelalaian, salik hendaknya menjaga hati dari terpautnya hati pada sesuatu selain Allah Swt., ia berkata: 


$$
\text { قال الجنيد : لا تكن عبدالله حقا ، وأنت لشيء سواه مسترقا }
$$

“Tidaklah engkau akan menjadi sebenar-benarnya hamba, sedangkan engkau (hatimu) masih terpaut pada sesuatu selain-Nya" (al-Hakim, 2005).

\section{Implementasi Wara'}

Pengimplementasian wara' dalam kehidupan sehari-hari terkadang dapat menemukan jalan terjal, sebagaimana dikemukakan Murtadha Muthahhari bahwa mungkin mudah bagi individu ketika dihadapkan pada situasi memilih antara nilai dengan anti nilai (baik dan buruk), namun tidak mudah ketika dihadapkan pada pertentangan nilai dengan nilai yakni antara satu ajaran kebaikan dengan kebaikan yang lain, seperti halnya rajin menabung dan sering bershadaqoh, dua amalan tersebut baik namun ketika kondisi materi tidak mencukupi maka akan ada yang ditinggalkan dan ada yang dilakukan (Muthahari, 2012). Oleh karenanya, wara' dapat mengambil peran dari kondisi tersebut, dengan mempertimbangkan baik dan buruk serta kebaikan yang lebih utama dilakukan saat itu dibandingkan kebaikan yang lain disesuaikan dengan kondisi yang melingkupi individu tersebut.

Pengukuran kondisi di sini sebagaimana yang dijelaskan Iqbal bahwa proses wara' seseorang melibatkan kesadaran manusia, dimana pembagian kesadaran terbagi menjadin dua kategori yakni apresiatif dan intensif (Iqbal, 2016). Apresiatif meliputi kesadaran seseorang yang menelaah individunya sendiri, intensif meliputi pada segala hal di luar dirinya, maka wara' berdiri menengahi dua kesadaran ini untuk mewujudkan sinkronisasi dalam berperilaku sehari-hari. Oleh karenanya, Imam Junaid menekankan Wara' lebih pada aspek penjagaan lisan dibandingkan anggota tubuh yang lain, karena dalam lisan sebagai penyambung hasil olah fikiran dengan aspek diluar diri dan diri sendiri, sehingga teramat rentan terjadi kekeliruan pemahaman dari pendengarnya yang berimbas pada dianggap menyelewengnya tasawuf oleh orang-orang yang tidak menempuh jalan suluk tersebut.

\section{Kesimpulan}

Dari hasil penelitian terhadap sumber-sember literatur yang mengkaji Imam Junaid terutama dalam ajaran wara', penulis menyimpulkan bahwa wara' adalah perilaku selektif yang melibatkan kesadaran seseorang untuk mengendalikan perilaku diri terutama mata, telinga, lisan dan hati. Proses intensitas dalam mengendalikan anggota tubuh meningkat sejauh mana pengetahuan salik tersebut, hingga kemudian mempengaruhi pada tingkatan yang dapat dicapai oleh salik dengan terus berupaya meningkatkan sikap kewaspadaannya terhadap gejolak diri dan apa yang hendak dilakukan diri. Penelitian ini selain dapat dijadikan pengetahuan 
tentang tema-tema ajaran tasawuf dapat juga dijadikan pijakan awal untuk untuk lebih mendalami lagi korelasi ajaran-ajaran tasawuf dengan kesadaran manusia yang sifatnya dinamis, dimana ajaran secara teoritis bersifat kaku sedang kesadaran realitas selalu berkembang, hal ini diperlukan agar lebih melenturkan ajaran tasawuf supaya mudah diaplikasikan dalam diri setiap individu. Oleh karenanya, kami merekomendasikan penelitian selanjutnya ditekankan pada satu kondisi lingkungan yang terjadi hari ini, semisal tentang wara' dalam dunia politik dengan mengambil sudut pandang dari sufi-sufi yang terjun dalam pemerintahan.

\section{Daftar Pustaka}

al-Hakim, S. (2005). Tajul Arifin. Qahirah: Darul asy-Syuruq. al-Hujwiri, A. H. (2007). Kasyful Mahjub. Al-Qahirah: Majlis A'la LisTsaqafah.

al-Junaid, A. Q. (1988). Rasail al-Junaid. Qahirah: Darul Kutub alMishriyyah.

al-Mazidi, A. F. (2006). Imam Junaid Sayyid at-Thaifataini. Lebanon: Darul Qutub Ilmiah.

al-Muhasibi, A. a.-H. (1956). Riayah LI Huquqillah. Libanon: Darul Qutub al-Alamiyah.

al-Qusyairi, A. Q. (2003). Risalah al-Qusyairiah. Darul Kutub al-Arabi:

Qahirah.

Asrifin. (n.d.). Tokoh-Tokoh Shufi. Surabaya: Karya Utama.

As-Sahmarani, A. (1987). At-Tasawwuf: Mansyauhu wa Mustalahatuhu. Bairut: Dar An-Nafis.

as-Sarraj, A. N. (1970). al-Luma'. Baghdad: Maktabah Al-Mutsanna.

Darmalaksana, W. (2020). Metode Penelitian Kualitatif Studi Pustaka dan Studi Lapangan. Pre-Print Digital Library UIN Sunan Gunung Djati Bandung.

Faza, A. M. (Maret 2017). Wawasan Hadits Nabi Tentang Wara'. Diroyah, 2, pp. 97-110.

Hamka. (1983). Tasauf. Jakarta: PT Pustaka Panjimas.

Hitti, P. K. (2006). History Of The Arabs. Jakarta: Serambi.

Iqbal, M. (2016). Rekonstruksi Pemikiran Religius Dalam Islam. Bandung: Mizan.

Kader, D. A. (2018). Imam Al-Junaid Al-Bagdadi (Pemimpin Kaum Sufi). Yogyakarta: Diva Press.

Kamba, M. N. (2018). Kidz Zaman Now. Tangerang Selatan: Iiman.

Kamba, M. N. (2020). Mencintai Allah Secara Merdeka. Tangerang: Iimani. Ashani, S., Harahap, M. R. P. A., \& Maulani, M. (2021). Trilogi Pemikiran Tasawuf Imam Junaid Al-Baghdadi (Mitsaq, Fana, dan Tauhid). Syifa al-Qulub, 5(2), 97-113. 
Muthahari, M. (2012). Manusia Seutuhnya. Jakarta: Sadra Press.

Nasr, S. H. (2002). Warisan Sufi. Yogyakarta: Pustaka Sufi.

Novianto, A., \& Mustadi, A. (2015). Analisis buku teks muatan tematik integratif, scientific approach, dan authentic assessment sekolah dasar. Jurnal Kependidikan: Penelitian Inovasi Pembelajaran, 45(1).

Zed, M. (2014). Metode Penelitian Kepustakaan. Jakarta: Yayasan Pustaka Obor Indonesia. 